\title{
The Impact of Covid-19 Pandemic on Growth of Retail Business in Indonesia
}

\author{
Sri Iswati ${ }^{1}$, Sudarsono ${ }^{2}$, Pudji Astuti ${ }^{3}$ \\ \{iswati.ssri@gmail.com¹, sudarsono@gmail.com², Puji_astuti@borobudur.ac.id ${ }^{3}$ \} \\ Universitas Borobudur, Jakarta, Indonesia ${ }^{1,2,3}$
}

\begin{abstract}
COVID-19 pandemic has an impact on various sectors, one of which is the economic sector. The impact is real felt both macro and micro. The retail business as one part of the economic sector is also experiencing the impact of the COVID-19 pandemic. This study used an exploitative and descriptive research method. The information employed in this investigation was quantitative. The independent variable and the dependent variable were linked in this study model. Inferential statistics and regression analysis were utilized to analyze the data in this study. According to studies, the retail industry is one of the business sectors that has suffered the most from the COVID-19 pandemic's impact. Several retail enterprises experienced losses as well, and several of them went out of business.
\end{abstract}

Keywords: COVID-19 Pandemic; Retail Business; Impact

\section{Introduction}

Indonesia is well-known for its democratic economic structure. The mandate of the national constitution is referred to as the democracy economic system, and the ideological and constitutional foundation is a legal product that controls all elements of national economic life. The Pancasila ideals as the value system of the Indonesian nation to infuse the five precepts into every economic action are the intellectual underpinning of the democracy economic system. The foundation of the democracy economy is regulated in the 1945 Constitution (before it was amended) Article 33 of the 1945 Constitution, paragraphs 1-3. One form of the democracy economy that is currently developing in Indonesia is the retail business sector. According to Kotler and Keller (2010), Retail is a collection of marketing tactics that businesses employ to achieve their marketing objectives [1].

All activities done by a firm to impact demand for its products are included in the retail mix, and all conceivable actions performed by a corporation may be summed up as a set of factors that include product, location, pricing, and promotion. In general, there are two types of retail: traditional retail and modern retail. In accordance with Presidential Regulation No. 112 of 2007 on Traditional Market Arrangement and Development and Minister of Trade Regulation No. 53 of 2008 on Guidelines for Structuring and Fostering Traditional Markets, Shopping Centers, and Modern Stores, traditional retailers are small and medium scale retailers, then in the buying and selling process it can be done through bargaining. Traditional retail is also defined as a shop or small shop/trader which is generally managed by the family, or in English it is called a mompop store. The management of traditional retail businesses is generally through a manual process 
or is not managed systematically. Examples of traditional retail are traditional market traders or grocery stores and stalls which are generally located in the middle of a residential area.

Meanwhile, modern retail such as minimarkets, supermarkets and shops managed systematically using a well-organized recording method. Generally, modern retail provides a shopping experience that provides convenience for its consumers. The development of modern retail in the form of minimarkets and supermarkets is influenced by various factors as incentives for their progress. First, driving factors from the demand side for modern retail services include economic growth and development. Economic growth has increased consumer welfare through per capita income growth. Furthermore, the increase in income led to an increase in services and consumption as well as a shopping experience with the demands of convenience [2].

Based on data of Statistics Indonesia in 2021, the development of the retail business sector is very encouraging and very prospective in the future, it can be seen in the following data that shows the contribution of the retail business sector to GDP during 2010 to 2020. According to Nielsen's research, the lower middle class group as a large portion of consumers who experienced a slowdown due to a decrease in total take-home income, an increase in utility prices as a result of a decrease in consumption, as well as purchases of various products that were held back by impulsive nature and reduced purchases of goods.

Meanwhile, the upper middle class is still taking a wait and see action, but there are indications that lifestyle spending tends to grow. During the COVID-19 pandemic, the impact felt by traders, that is the decrease in income due to lack of buyers because people are required to reduce activities outside the home that affect the economy of traders. When traders do not get social security from their own work, illness becomes their own responsibility. Based on data obtained by researchers from the Indonesian Market Traders Association (Ikappi) released the fact that in the past month the turnover of traditional market traders has continued to decline by up to 60 percent during the Covid-19 outbreak.

Economic pressure caused by COVID-19 pandemic makes the credit demand sluggish. Retail entrepreneurs have complained about the difficulty of accessing bank credit to survive and operate in the midst of the Covid-19 Pandemic. In fact, the retail sector is a sector that supports household consumption which contributes greatly to GDP. Due to the pandemic, as many as 90 shops have closed including supermarkets, department stores and tenants during the last three months at the beginning of the year. Retailers are currently in dire need of capital to be able to keep their business moving in the midst of a pandemic.

Primarily this working capital requirement can be met through loans, considering that retailers' finances are very depressed. Meanwhile, funds in the banking sector are very abundant due to the stimulus from the government and the continued increase in third party funds (DPK). The funds are intended for banks to be able to disburse working capital loans to business actors. The interest given by the government is lower than loans in general that is 2.8 percent. Based on this background, this study aimed to analyze and describe the influence of traditional market growth, modern market growth, per capita expenditure, retail sector investment and retail sector banking credit simultaneously on the performance of the retail business sector.

\section{Literature Review}

\subsection{Economic Development Theory}


Economic development, according to Adam Smith in Suryana (2010), is a process that combines population expansion and technical improvement [3]. To fulfill domestic demand, a country's population growth must be balanced with technical advancements in production. Economic progress, according to Schumpeter in Sukirno (2012), is a spontaneous and unstoppable process rather than a smooth and steady one [4]. Changes, particularly in the industrial and commercial industries, drive economic development. According to this concept, economic growth occurs through time and always leads to a positive improvement in everything so that it can be better than before. By utilizing industrial technology and generating economic competitiveness, industry and commerce will encapsulate all inventiveness in economic progress.

Economic development, according to Arsyad (2010), is a process that includes the formation of new institutions, the development of alternative industries, the improvement of existing workforce capacity to produce better products and services, the identification of new markets, the transfer of knowledge, and the development of new businesses [5]. Economic development is a multifaceted process that includes all key changes in economic structure, social transformation, poverty reduction, inequality reduction, and unemployment reduction [6]. Sukirno (2012) Economic development is defined as "economic growth combined with change," according to the author [4]. It means that economic development in a country is not only measured by the increase in the production of goods and services that apply in economic activities such as the development of education, technological development, improvement in health, improvement of available infrastructure and increase in income and prosperity of the community. .

Suryana (2010) states four models of economic development among others : economic development model oriented to growth, Creating jobs, reducing poverty, and a strategic economic paradigm centered on fundamental requirements are all priorities [3]. Based on the development model, all of them aimed at improving the quality of life, increasing goods and services, creating new jobs at a decent wage, with the hope of achieving a minimum standard of living for each household. Based on this definition, it can be seen that economic development means the existence of a continuous development process that is adding and improving everything for the better. With the development process, it is expected that an increase in income will last for the long term. The development of economic sectors that takes place in each region in the territory of Indonesia must be adjusted to the potential and priorities of each region so that the overall development is a unified whole in the context of realizing national development [7].

\subsection{Economic Growth}

Nafziger (2011) states that economic growth is an increase of country's production or per capita income. The production is calculated by GNP (Gross National Product - Gross National Income) or GNI (Gross National Income) are two terms for the same thing. - Gross National Income) that is the total output of the country. Economic growth also means the increase of the economic capacity of a region in a certain time. According to Subandi (2014), Economic growth is defined as a rise in GDP/GNP, regardless of whether the increase is more or lesser than population growth or whether the economic structure has changed or not [8]. Meanwhile, Lincolin Arsyad (2010) states that economic growth can be defined as the developmental milestones of a country's production of goods and services, such as increasing the amount of industrial goods produced, developing infrastructure, increasing the number of schools, expanding the service sector, and growing capital goods production [5]. 


\subsection{Democracy Economy}

The concept of a democracy economy is stated through the constitution of the Republic of Indonesia Article 33 of the 1945 Constitution that mentions in detail (1) the economy's preparation as a collaborative endeavor based on the kinship concept. (2) The state must control production branches that are vital to the state and have an impact on people's livelihoods. (3) The state shall manage the ground, water, and all riches contained within, and employ it for the people's best benefit. The state plays a very important role in the democracy economic system. According to Article 27 paragraph 2 and Article 34, the state's role in the democracy economic system is to: (1) develop BUMN (2) develop cooperatives; (3) ensure the use of the earth, water, and all the wealth contained therein for the greatest prosperity of the people; (4) fulfill every citizen's right to a job and a decent living; and (5) care for the poor and neglected children.

According to Simarmata (2010), the phrase "democratic economy" is defined as an economic system in which production is carried out by all, for all, and under the control of society's members, as stated in the explanation of Chapter 33 of the 1945 Constitution. As a result, engagement of all people in production activities is one of the cornerstones of democracy economy. Democracy economics, according to Siagian (2011), is the economic activity of individuals in a country or region that is typically trailing behind the average economy of the country or territory concerned. Another definition is that the democratic economy is an indigenous economy (democracy economy is indigenous economy), rather than economic activity that originate outside of the community (external economy). As a result, democratic economics refers to the economy or economic growth of community organizations that occurs slowly and in line with the conditions that exist inside the groups.

The democratic economy may be regarded from two perspectives: first, the approach of economic activity from small-scale economic players, known as the democracy economy; and second, the approach of economic activity from large-scale economic actors, known as the democracy economy. The empowerment of the democratic economy, according to this perspective, is the empowering of small-scale economic players. Second, participatory development refers to the economic system approach, often known as economic democracy or a democratic development system. The empowerment of the democracy economy is based on this second method, and it aims to apply democratic values to development. This indicates that a democratic economy is an economic system that incorporates all levels of society in the growth process, with each layer acting as the driving force for progress. A democratic economy, often known as a democracy economic system, is the second approach.

According to the definition above, democracy economy is the economic development of community groups that involve all levels of society in the development process related to aspects of economic democracy, justice, and alignments with the democracy economy that relies on a fair market mechanism and involves all levels of society in the development process, and acts fairly for the entire community with the goal of improving the economic welfare of the majority of the community.

\section{Methodology}

The research approach utilized in this study was exploitative and descriptive. According to Malhotra (2012), exploratory research is used to study an issue or condition in order to obtain a better understanding of it. Descriptive research, on the other hand, tries to discover something. Descriptive research includes a clear presentation of the problems, precise hypotheses, and all 
of the necessary information. The research approach employed in this study was quantitative methodologies. Quantitative techniques, according to Sugiyono (2016), are research methods based on the positivist philosophy, used to analyze specific populations or samples, data collecting utilized as research instruments, and quantitative/statistical data processing with the goal of testing prepared hypotheses [9]. The research design is as shown in Figure 1.

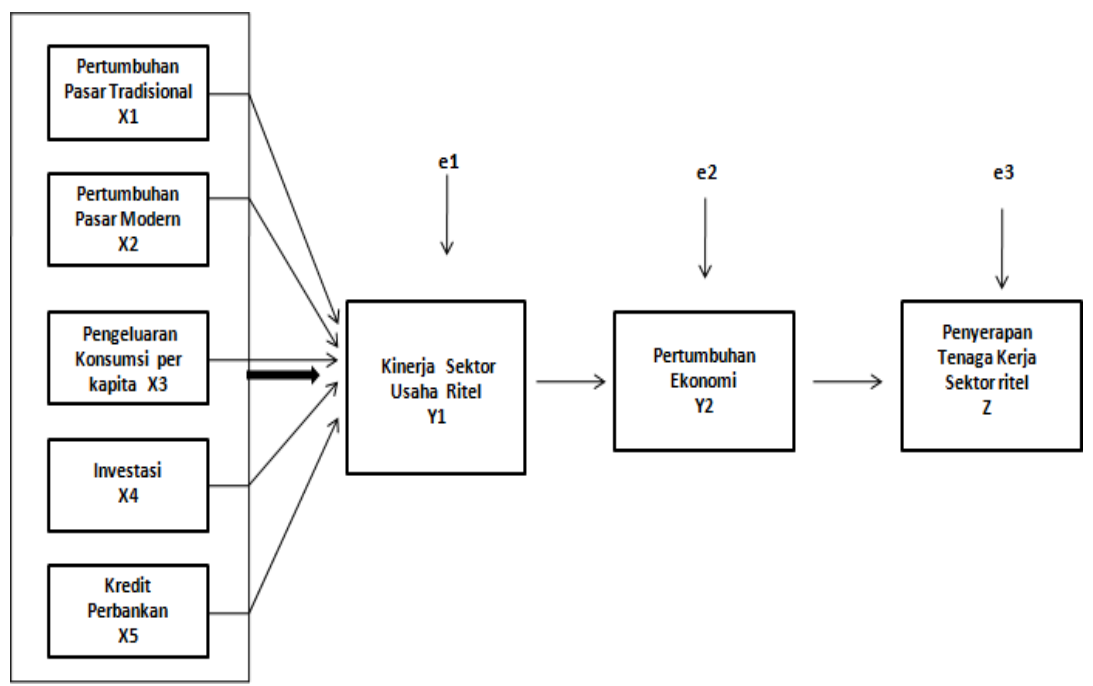

Fig. 1. Research Design

This study relied on quantitative data in the form of numbers that could be measured. Secondary data was used in this study, namely data in the form of quarterly / quarterly reports that have been compiled and published by related parties, namely the Central Statistics Agency, National Development Planning Agency, Bank Indonesia, Ministry of Trade, Ministry of Industry, Ministry of Cooperatives and MSMEs, Ministry of Manpower \& Transmigration, in various editions, as well as various other relevant sources such as journals, dissertations, in various editions, as well as various other relevant sources such as journals, dissertations, in various The independent variable and the dependent variable were linked in this study model. Inferential statistics and regression analysis were utilized to analyze the data in this study. Depending on the type of data and quantitative data analysis [9]. Following the collection of data, hypothesis testing was used to see if there was a significant relationship between the independent factors and the dependent variable.

\section{Results and Discussion}

\subsection{The Effect of Traditional Market Growth, Modern Market Growth, Per Capita Consumption Expenditure, Retail Sector Investment and Retail Sector Banking Loans Simultaneously on Retail Business Sector Performance}

In conjunction with the growth of the Indonesian economy, the retail business sector or retail industry began to emerge in the 1980s. This is due to the emergence of the middle class, which 
has resulted in an increase in demand for supermarkets and department shops (convenience stores) in metropolitan areas. The retail industry is one of the industries that has suffered the most damage as a result of the COVID-19 epidemic. Several retail companies suffered losses, even a few of their businesses went out of business. There are also those who have to face bankruptcy lawsuits or requests for Postponement of Debt Payment Obligations (PKPU). The Covid-19 vaccination and economic recovery are positive catalysts that will lift the retail business again. However, current conditions have not significantly boosted the recovery of the retail industry. Thus, the researcher suggests to the government to consider providing incentives to retail business actors, including modern retailers. The incentive can be in the form of providing a stimulus from the National Economic Recovery (PEN) program.

The results of the first hypothesis showed that the growth of the traditional market, the growth of the modern market, consumption expenditure per capita, investment in the retail sector, and banking credit in the retail sector affected the performance of the retail business sector. The results of this study had been proven to have forecasting ability or high predictive ability on the behavior of the dependent variable that is characterized by a high coefficient of determination above 50 percent that is 87.40 percent. In addition, this hypothesis also gives an accurate feasibility test for future estimation purposes if each variable uses a 95 percent confidence level (accuracy of the estimates of the parameter). Likewise, the results of this study meet the element of theoretical plausability that results in accordance with expectations and the theory as the basis of their thinking. It proves the accuracy of the researchers in selecting the five determinants that affect the Performance of the Retail Business Sector.

\subsection{The Effect of Traditional Market Growth on Retail Business Sector Performance}

The rise of conventional marketplaces has a large and favorable influence on the success of the retail business sector, according to statistical assessments. The positive interpretation in economics means that the increase and growth of traditional markets is also followed by the increase in the performance of the retail business sector. Meanwhile, the significant understanding means that the Traditional Market Growth hypothesis can be proven convincingly and significantly affects the Retail Business Sector Performance. The level of significance is expressed in numbers that indicate the possibility or risk of error for the tests carried out where in this study the number 5 percent or 0.05 was used. The significance level of the t-test / partial test was 0.0025 , which is less than 0.05 , indicating that the expansion of conventional marketplaces had a substantial impact on the performance of the retail business sector.

\subsection{The Effect of Modern Market Growth on Retail Business Sector Performance}

The findings of statistical computations revealed that modern market growth had a considerable and favorable impact on the retail business sector's performance. The positive interpretation in the economics means that the increase and growth of the modern market was followed by an increase in the performance of the retail business sector. Meanwhile, the significant understanding means that the Modern Market Growth hypothesis is convincingly and meaningfully proven to affect the Performance of the Retail Business Sector. The level of significance was expressed in numbers that indicate the possibility or risk of error for the tests carried out where in this study the number 5 percent or 0.05 used. With a significance level of 0.0000 or less than 0.05 , the findings of the t-test / partial test indicate that modern market growth had a substantial impact on the performance of the retail business sector. 
The results of this study were supported by empirical data and facts that the growth of the modern retail industry in the country showed a positive trend. It is reflected in encouraging growth in the consumption of daily necessities or fast moving consumer goods (FCMG) compared to last year. FCMG consisted of 58 product categories had been the mainstay of modern retail sales. During the period April 2018-April 2019, FCMG consumption in contemporary retail in Indonesia increased by 6.6 percent, with data for the minimarket format increasing by 12.1 percent and supermarket and hypermarket formats decreasing by $-6.8 \%$. For the record, FCMG consumption in Indonesia increased by 1.8 percent from April 2018 to April 2019. Despite being significantly behind the inflation rate, this result was far better than the preceding quarter, which only rose by 1\% from April 2017 to April 2018. Regarding the growth of the retail industry in the country, it is predicted that there will be growth of up to $10 \%$ by the

end of 2019. This figure was higher than last year realized claims that were in the range of $8 \%$ $8.5 \%$.

\section{Conculsion}

Based on the results, it can be concluded :

a. The growth of the traditional market, the growth of the modern market, consumption expenditure per capita, investment in the retail sector and banking credit in the retail sector are some of the factors that had a very significant influence on the performance of the Indonesian retail business sector.

b. With the increase of the growth of the traditional market, it contributes and had a significant influence on the performance of the Indonesian retail business sector.

c. Modern market growth was able to boost and improve the performance of the Indonesian retail business sector.

d. Consumption expenditure per capita was very important factor and had a contribution and effect on the performance of the Indonesian retail business sector.

e. A conducive climate and regulatory reformed by the government for retail sector investment, both from foreign investment and domestic investment, are able to improve the performance of the Indonesian retail business sector. The distribution of bank credit from state-owned and private banks, Islamic banks and rural banks, especially to the retail sector, has an important role and contribution to increase the performance of the Indonesian retail sector.

f. The performance and contribution of the retail business sector to Indonesia GDP over the last 10 years and during the COVID-19 pandemic greatly affected Indonesia economic growth.

g. Economic growth contributed by the retail business sector had a very significant influence in creating new jobs, job opportunities and employment in the retail business sector in Indonesia.

h. Economic growth contributed by the retail business sector had a very significant influence in creating new jobs, job opportunities and employment in the retail business sector in Indonesia.

Based on the conclusion above, the suggestions of this research among others :

a. The implementation of the omnichannel concept must be massively carried out by retail businesses if they want the significant growth of the business. With the omnichannel concept, retailers can serve consumers both online and offline. For instance the consumers 
can order goods from a place through an online system, then take their order at an offline store.

b. The Covid-19 pandemic should be a turning point momentum for traditional markets from adversity, not the opposite as a "dead point". The important role of digital platforms to help market traders continue to sell online. Thus, traders can continue to sell and consumer can easily get the desired goods without having to leave the house. The presence of the Corona virus has accelerated the digitization process, including the digitization of the economy. This virus forces humans to limit the physical contact activities. As a result, various social, economic and business activities, as well as public services must be carried out online.

c. In facing COVID-19 pandemic and to assist the modern retail business sector, the government is expected to provide a stimulus in the form of tax relaxation. The government must continue to restore the economic sector. Acceleration of the vaccination program is one that is expected to boost the economy. For modern retailers, it is necessary to implement a strategy of selling products with their own packaging and brands or private labels to deal with the decline in consumption and purchasing power in the midst of society and maintain loyal consumers who are starting to switch to e-commerce platforms one by one. promotions offered. These products allow modern retailers to sell products at more affordable prices and the same quality as similar products.

d. Consumption Expenditures per capita Indonesia has a large contribution to gross domestic product (GDP) specifically in spending a goods and services for household consumption. Therefore, for business actors during the COVID-19 pandemic, it is recommended to prioritize the online sales system because the online shopping system has the opportunity to gain greater profits due to wider market.

e. It is necessary to reform policies to attract investors in the retail sector by making changes to investment law. The improvement in the domestic investment is the fact that the country has failed to develop the institutional infrastructure to attract foreign investment because it has too much confidence in its market potential and abundant natural resources.

f. The national banking sector is expected to provide a larger portion of credit to the retail business sector so that this sector can develop rapidly and massively considering the potential of this sector is quite promising and makes a significant contribution to Indonesia economic growth.

g. Government is expected to continue encourage the retail business to grow in order to increase national economic growth. Various efforts must be made to maintain the performance of the retail sector during the pandemic. Among others by providing economic stimulus for the retail sector, opening trade activities with strict health protocols, and supporting digital transformation. The government should also provide incentives for retail businesses. Namely, tax incentives. With tax incentives, retail business actors' expenditure burden is reduced to maintain company cash flow. It is expected that the stimulus for the retail sector can further encourage the domestic economy.

h. The government through the Ministry of Trade is expected to be able to oversee and supervise the implementation of the Minister of Trade Regulation No. 55/2019 concerning the Indonesian National Qualifications Framework (KKNI) for the Modern Retail Sector in order to increase the competitiveness and competence of the workforce in the modern retail industry sector so that all modern retailers can implement it in Indonesia. To overcome employment problems during the COVID-19 pandemic, employers, workers, trade unions, and the government must be able to establish cooperation in anticipating layoffs including taking steps such as employers and workers with trade unions conduct a transparent dialogue from an early age in anticipating labor conditions. This dialogue is the main way 
to build a common understanding to deal with the impact of the Covid-19 pandemic for both companies and workers. Then, the government also needs to carry out an employment mitigation plan in the face of a deteriorating work situation due to the economic crisis as a result of the Covid-19 pandemic. This can be done by implementing government programs that can absorb a large workforce and skills development support programs such as providing Pre-Employment Cards for people who have just graduated from school and are looking for work as well as realizing and monitoring the implementation of incentive packages for employers and workers to survive. An important contribution to the increasing performance of the Indonesian retail sector.

\section{References}

[1] Kotler P, Keller KL. 2010. Markerting Management. Jakarta : Erlangga.

[2] Kualitatif, Bandung : UPI

[3] Suryana, 2010, Metode Penelitian Model Praktis Penelitian Kuantitatif dan Syahida.

[4] Sukirno S. 2004. Makro Ekonomi Teori Pengantar. Edisi III. Jakarta: PT Raja

[5] Arsyad L. 2010. Ekonomi Pembangunan, Edisi kelima. Yogyakarta: UPP Grafindo Persada.

[6] Todaro M, Smith S. 2008. Pembangunan Ekonomi Jilid 1. Jakarta : Erlangga.

[7] Coirullah. Ekonomi Pembangunan. (2010)

[8] Ahmad Subandi. 2014. Ilmu Dakwah : Pengantar kearah Metodologi. Bandung :

[9] Sugiyono. 2016. Metode Penelitian Kuantitatif, Kualitatif dan R\&D. Bandung:

[10] Permendagri No.53 Tahun 2008

[11] Perpres No. 112 Tahun 2007

[12] UUD 1945 